\title{
Chronic necrotizing pulmonary aspergillosis in an immunocompetent patient after the surgery of hydatid cyst
}

\author{
Nagehan EMIRALIOĞLU ${ }^{1}$ \\ Hatice Nursun ÖZCAN ${ }^{2}$ \\ Diclehan ORHAN ${ }^{3}$ \\ Mithat HALILOĞLU² \\ Ali Bülent CENGiz ${ }^{4}$ \\ Elmas Ebru YALÇIN ${ }^{1}$ \\ Deniz DOĞRU ERSÖZ ${ }^{1}$ \\ Nural KIPER ${ }^{1}$ \\ Hayriye Uğur ÖZÇELiK ${ }^{1}$
}

${ }^{1}$ Division of Pediatric Chest Diseases, Faculty of Medicine, Hacettepe University, Children Hospital, Ankara, Turkey

${ }^{1}$ Hacettepe Üniversitesi Tıp Fakültesi Çocuk Hastanesi, Çocuk Göğüs Hastalıkları Bilim Dalı, Ankara, Türkiye

2 Department of Radiology, Faculty of Medicine, Hacettepe University, Children Hospital, Ankara, Turkey

2 Hacettepe Üniversitesi Tıp Fakültesi Çocuk Hastanesi, Radyoloji Anabilim Dalı, Ankara, Türkiye

${ }^{3}$ Department of Pediatric Pathology, Faculty of Medicine, Hacettepe University, Children Hospital, Ankara, Turkey

${ }^{3}$ Hacettepe Üniversitesi Tıp Fakültesi Çocuk Hastanesi, Pediatrik Patoloji Bilim Dalı, Ankara, Türkiye

${ }^{4}$ Department of Pediatric Infection Diseases, Faculty of Medicine, Hacettepe University, Children Hospital, Ankara, Turkey

${ }^{4}$ Hacettepe Üniversitesi Tıp Fakültesi Çocuk Hastanesi, Çocuk Infeksiyon Hastalıkları Bilim Dalı, Ankara, Türkiye

\begin{abstract}
SUMMARY
Chronic necrotizing pulmonary aspergillosis in an immunocompetent patient after the surgery of hydatid cyst

Chronic necrotizing pulmonary aspergillosis (CNPA) is a condition caused by the ubiquitous fungus Aspergillus fumigatus in nonimmunocompromised individuals. Numerous underlying conditions have been associated with CNPA. Tuberculosis, non-tuberculous mycobacterial infection and allergic bronchopulmonary aspergillosis (ABPA) remain the predominant risk factors for development of CNPA. Development of CNPA in echinococcal cyst cavities is very rare and the optimal therapeutic regimen and treatment duration have not been established. Here, we present a case of CNPA developed six years after the cystectomy operation of hydatid cyst and treated with voriconazole successfully.
\end{abstract}

Key words: Pulmonary aspergillosis, hydatid cyst, voriconazole, immunocompetent

\section{ÖZET}

Bağışıklık sistemi normal bir olguda kist hidatik cerrahisi sonrası kronik nekrotizan pulmoner aspergillozis gelişimi

Kronik nekrotizan pulmoner aspergillozis, bağısıklık sistemi baskılanmamış olan kişilerde çevrede sıklıkla görülen Aspergillus fumigatus'a bağlı gelisen bir durumdur. Kronik nekrotizan pulmoner aspergillozis ile ilişkili altta yatan farklı nedenler vardır. Tüberküloz, tüberküloz dışı mikobakteri infeksiyonları, allerjik bronkopulmoner aspergillosis kronik nekrotizan pulmoner aspergillozis gelişiminde öncülük eden altta yatan risk faktörleridir. Ekinokok kist kavitesinde kronik nekrotizan pulmoner aspergillozis gelişimi nadir görülmektedir; optimal

\section{Yazışma Adresi (Address for Correspondence)}

Dr. Nagehan EMIRALIOĞLU

Hacettepe Üniversitesi Tıp Fakültesi Cocuk Hastanesi, Çocuk Göğüs Hastalıkları Bilim Dalı, ANKARA - TURKEY

e-mail: drnagehan@yahoo.com 
tedavi seçimi ve tedavi süresi de kesin bilinmemektedir. Burada hidatik kist tanısıla kistektomi operasyonundan altı yıl sonra kronik nekrotizan pulmoner aspergillozis gelişen ve varikanazol ile başarılı şekilde tedavi edilen bir olgu sunulmuştur.

Anahtar kelimeler: Pulmoner aspergillozis, hidatik kist, varikanazol, immünkompetan

\section{INTRODUCTION}

Chronic necrotizing pulmonary aspergillosis (CNPA) is one type of chronic pulmonary aspergillosis (CPA) and a relatively uncommon manifestation of infection with Aspergillus spp. which mainly affects immunocompromised or immunostressed individuals with underlying lung diseases, such as tuberculosis, chronic obstructive pulmonary disease, allergic bronchopulmonary aspergillosis and pneumothorax $(1,2)$. Very few cases of disseminated aspergillosis in immunocompetent individuals have been reported in the literature (3).

Because of the rarity of CPA, the optimum treatment regime has not been delineated. There are no randomized trials of therapy; many clinical cases and case series have reported the usefulness of the various antifungal agents that are available. Although surgical resection is the radical treatment, there are many patients who are not eligible for surgery. Long-term treatment with antifungal agents is performed in most cases $(4,5)$.

Pulmonary aspergillosis has also been reported, though rarely, in pulmonary cavities as a consequence of the removal of a hydatid cyst (6). Here, we present a case of CNPA developed six years after the cystectomy operation of hydatid cyst and treated with voriconazole successfully.

\section{CASE REPORT}

A 14-year-old girl presented to pediatric emergency with dyspnea and hemoptysis. In her previous medical history she had been diagnosed with hydatid cyst in upper lobe of the both lungs and cystectomy was performed six years ago. She had no symptoms during the past four years, but two years ago she was treated with cavitary pneumonia and received antibiotic treatment. In her family history there was not a characteristic finding and tuberculosis was negative in her contact history.

On her physical examination her weight and height was under 3 percentile. Her respiratory rate was 24/ minute and transcutaneous oxygen saturation in room air was $96 \%$. On auscultation, breath sounds were decreased on middle and upper part of the right lung and other physical findings were normal. Blood count and biochemistry analysis were in normal range; however C-reactive protein level and erythrocyte sedimentation rate were elevated.

Chest radiography demonstrated mass like opacity in the upper and middle lobe of right lung. Thorax computed tomography (CT) revealed an intensely enhancing large mass with necrotic characteristics in the right upper and middle lobe of the lung. The lesion was extending from the hilus to the peripheral part of the lung, mediastinum and surrounding the right main bronchus. There was a cavitary lesion in the upper lobe of the right lung and parenchymal nodules were detected in the right lung. Also the right main pulmonary artery was obstructed with the lesion (Figure 1). Her echocardiographic evaluation revealed out no blood flow in the right main pulmonary artery due to mass effect and mild pulmonary hypertension. The abdominal ultrasonography was performed to rule out malignancy and found normal.

For the differential diagnosis of the mass, a CT-guided aspiration specimen was obtained from the lesional area in the right upper lobe. Biopsy specimens revealed necrotic lung tissue with septate hyphae and these necrotic zones showed positive periodic acidschiff (PAS) staining for septate hyphae. An acid fast bacillus staining was negative. On immunohistochemical examination, these septate hyphae had positive staining with aspergillus antibodies and the remaining part of the specimen was characterized with mixed inflammation with fibroblastic and vascular proliferation (Figure 2). According to the histological findings, the diagnosis of CNPA was considered. Aspergillus specific Ig E was positive and Aspergillus galactomannan was in normal range. Immunological evaluation has been performed. C3, C4, lymphocyte subsets were in normal range, NBT test was found $100 \%$; Ig G, Ig M, Ig E levels were elevated and tuberculin skin test was negative. The patient was immediately started on a 2-month course of intravenous voriconazole at $8 \mathrm{mg} / \mathrm{kg} /$ day divided two dosages after the loading dosage of $12 \mathrm{mg} / \mathrm{kg} /$ day for one day. Follow-up at two months the patient was discharged with orally voriconazole and reported continued general good health with no complaints. Follow up chest X-Rays revealed decreasing size of the large mass. On the third month of treatment 

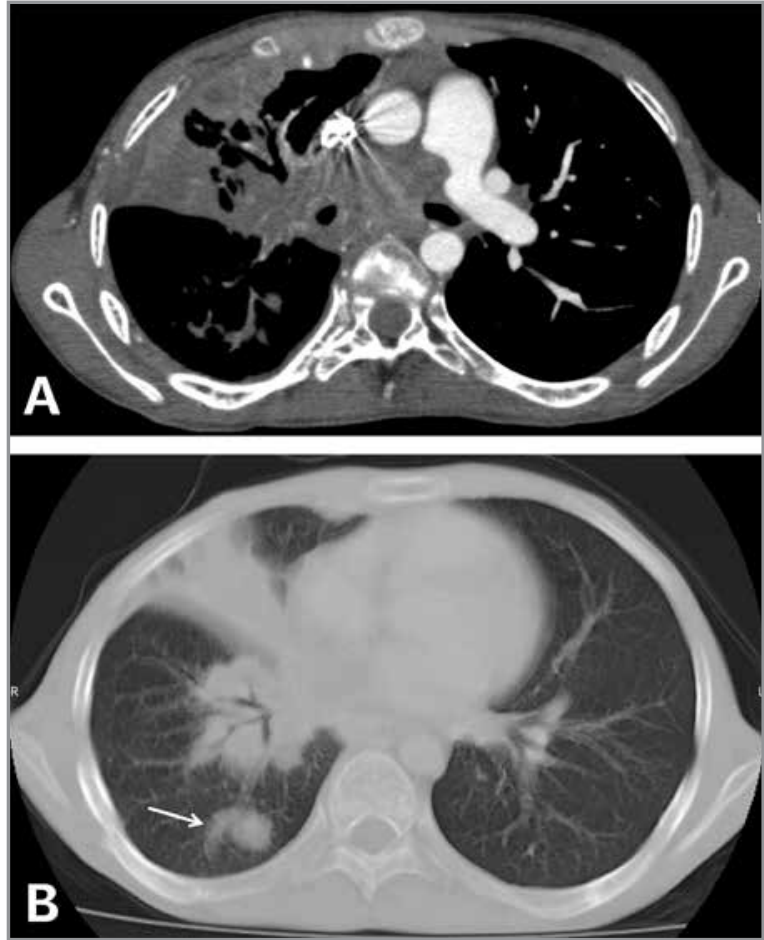

Figure 1. (A) Axial contrast enhanced $C T$ images demonstrate large hilar mass involving the right main pulmonary artery and right main bronchus. The mass was extending to the right upper and middle lobe with cavitations. (B) Also note the parenchymal nodule in the right lower lobe in the lung window (arrow).

thorax CT revealed out significant decrease on mass size (Figure 3). Medical treatment was planned to be completed at six months.

\section{DISCUSSION}

The spectrum of pulmonary aspergillosis manifestations is wide and relatively non-specific, ranging from

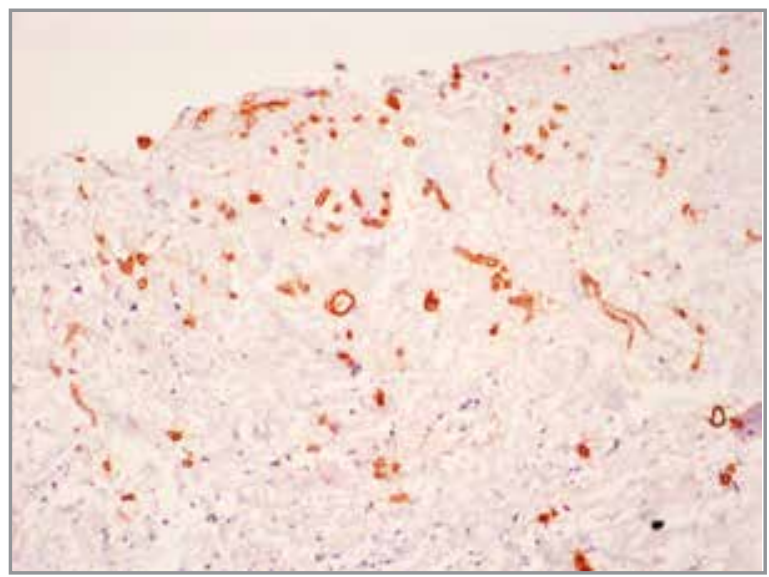

Figure 2. Immunohistochemical staininig for aspergillus antigen (Immunperoxidase, orginal magnification $\times 100$ ).
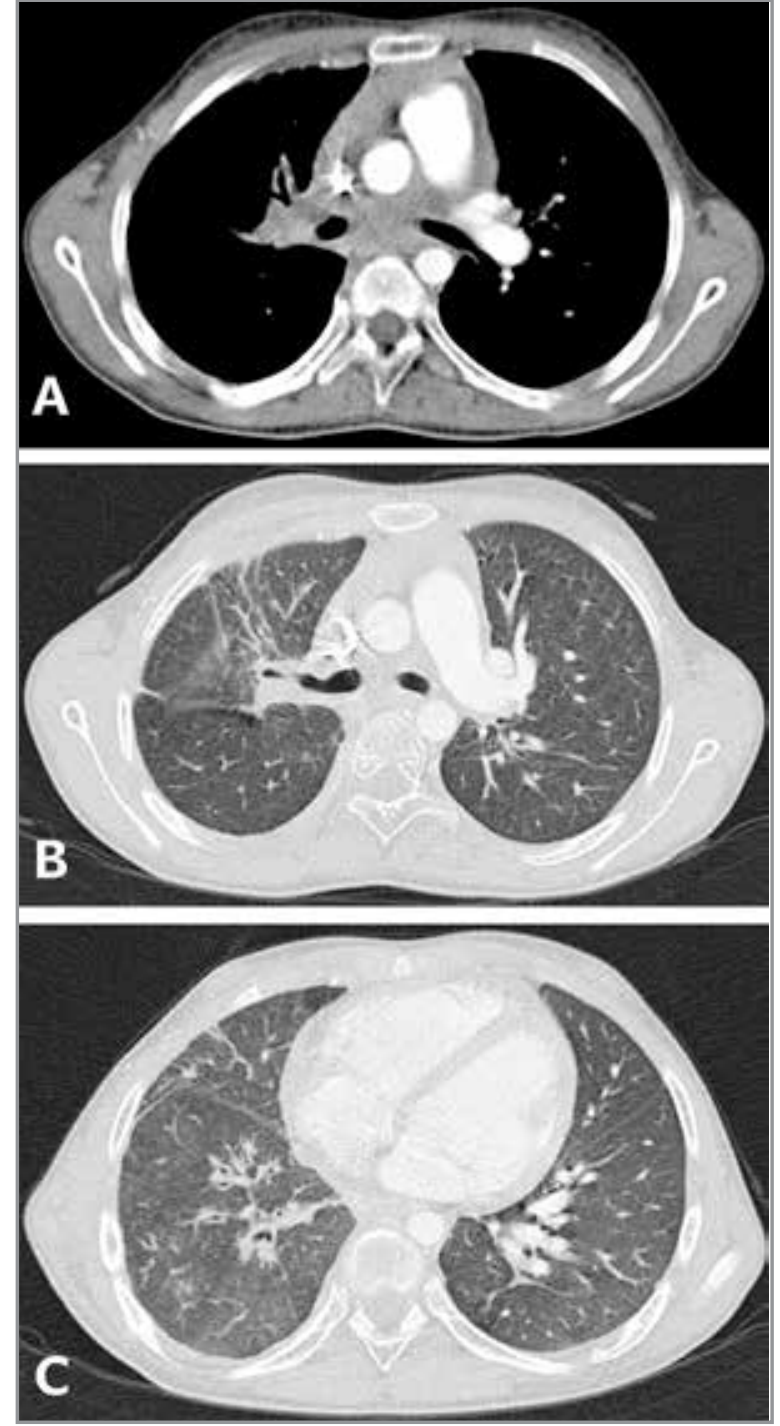

Figure 3. (A,B) After the treatment axial contrast enhanced CT scans show the significant reduction of the mass. (C) Note the disappearance of the parenchymal nodule in the right lower lobe.

cough, fever, malaise, fatigue, hemoptysis, shortness of breath, and unintentional weight loss (7). CNPA is among the rarest of the types, and is characterized as a slowly progressive form of pulmonary aspergillosis. The majority of CNPA cases arise as a complication of pre-existing chronic lung diseases, such as emphysema, sarcoidosis, tuberculosis sequelae, and other fibrotic lung diseases. An altered systemic immune status, such as that due to diabetes mellitus, chronic liver disease, malnutrition, connective tissue diseases, alcoholism, and low-dose corticosteroid therapy, is also considered a risk factor for CNPA (1). While immunocompromise or immunostress predisposes an individual to 
Aspergillus spp. infection, immunocompetent individuals are also susceptible (7). In our case, the patient had a normal immune status.

Pulmonary aspergillosis frequently complicates an existing cavity that is due to tuberculosis in most cases. Nevertheless, aspergillosis can develop in any kind of pulmonary cavity, including cavities resulting from removal of a hydatid cyst. Regnard et al. reported growth of aspergilloma in a post-tuberculosis cavity in $69 \%$ of a series of 89 cases with aspergilloma (8). So we evaluated our patient for tuberculosis and tuberculin skin test was negative. Development of aspergillosis in hydatid cyst cavities is very rare. Aspergilloma in an operated hydatid cyst cavity was reported after many years in one case and after 6 months in another and they are both adults $(9,10)$. Our patient was diagnosed with aspergillosis six years after the hydatid cyst operation, however cavitary pneumonia was diagnosed four years after the operation.

Regardless of the sufferer's immune status, diagnosis of CNPA relies on clinical and radiographic findings. Antifungal therapy is the treatment mainstay for patients diagnosed with CNPA. Antifungal agents with anti-Aspergillus activity include itraconazole, amphotericin B preparations, micafungin, and voriconazole. For treatment of chronic pulmonary aspergillosis, the acute-exacerbation-phase and subsequent maintenance therapy are prolonged in many patients. Therefore, it is important to adequately select injection for acute-exacerbation- phase treatment and oral agents for maintenance therapy at the outpatient clinic. Although initial reports advocated intravenous amphotericin B, itraconazole is now regarded as a better initial therapy because of its efficacy and minimal toxicity. The Infectious Diseases Society of America (IDSA) recommends the use of oral itraconazole for the treatment of CNPA and they also recommend chronic cavitary and chronic necrotizing pulmonary aspergillosis require long term medical therapy. However, the treatment outcomes have varied among studies, and data on the long-term survival of patients with CNPA are still scarce. Most clinical experience with the use of itraconazole is based on European studies, which have reported good responses with itraconazole; improvement or cure was described in $90 \%$ of the patients treated (11).

Here we preferred the new triazole voriconazole treatment. On voriconazole, very few retrospective and only one prospective therapeutic studies of CNPA have been performed. Saito et al. suggested that voriconazole provides effective therapy of CNPA in non-immunocompromised patients with an acceptable level of toxicity in Japan (4). On the other hand, the drug is known to cause adverse reactions, such as liver disorder and abnormal vision. Voriconazole has an acceptable tolerability. Almost all the patients were able to continue the treatment. The monitoring of hepatic function is important during voriconazole therapy. We did not see any adverse reaction due to voriconazole during her clinical observation.

\section{CONCLUSION}

To the best of our knowledge, this is the first reported pediatric case in the literature of CNPA occurring in an immunocompetent patient after the surgery of hydatid cyst and treated successfully with long term voriconazole.

\section{REFERENCES}

1. Parra I, Remacha A, Rezusta A, Suarez D, Suarez J, Herreras $J A$, et al. Chronic necrotizing pulmonary aspergillosis. Med Mycol 2004;42:369-71.

2. Smith NL, Denning DW. Underlying conditions in chronic pulmonary aspergillosis including simple aspergilloma. Eur Respir J 2011;37:865-72.

3. Shakoor MT, Ayub S, Ayub Z, Mahmood F. Fulminant invasive aspergillosis of the mediastinum in an immunocompetent host: a case report. J Med Case Rep 2012;6:311.

4. Saito T, Fujiuchi S, Tao Y, Sasaki Y, Ogawa K, Suzuki K, et al. Efficacy and safety of voriconazole in the treatment of chronic pulmonary aspergillosis: experience in Japan. Infection 2012;40:661-7.

5. Nam HS, Jeon K, Um SW, Suh GY, Chung MP, Kim H, et al. Clinical characteristics and treatment outcomes of chronic necrotizing pulmonary aspergillosis: a review of 43 cases. Int J Infect Dis 2010;14:e479-82.

6. Soubani $A O$, Chandrasekar PH. The clinical spectrum of pulmonary aspergillosis. Chest 2002;121:1988-99.

7. Jin E, Wang LM, Li QY, Feng X, Ma SL. Chronic necrotizing pulmonary aspergillosis in an immunocompetent patient: report of a rare case. Infection 2014;42:565-8.

8. Regnard JF, Icard P, Nicolosi M, Spagiarri L, Magdeleinat $P$, Jauffret B, et al. Aspergilloma: a series of 89 surgical cases. Ann Thorac Surg 2000;69:898-903.

9. Ulasan NG, Dural K, Yildirim E, Ozisik K, Sakinci U. An intracavitary aspergilloma after eccinococcal cystectomy. J Cardiovasc Surg 2003;44:289-90.

10. Aydemir B, Aydemir C, Okay T, Celik M, Dogusoy I. An aspergilloma in echinicoccal cyst cavity. Thorac CardiovasC Surg 2006;54:353-5.

11. Walsh TJ, Anaissie EJ, Denning DW, Herbrecht $R$, Kontoyiannis DP, Marr KA, et al. Treatment of aspergillosis: clinical practice guidelines of the Infectious Diseases Society of America. Clin Infect Dis 2008;46:327-60. 